\title{
Reproductive characteristics of rabbit bucks administered Panax ginseng extracts
}

Iwuji, T. C ${ }^{1}$., Herbert, U²., Oguike. M. A². and Obikaonu, H. O'.

1 Department of Animal Science and Technology, Federal University of Technology, P. M. B. 1526, Owerri, Imo State, Nigeria.

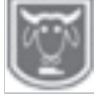

2 Department of Animal Breeding and Physiology, Michael Okpara University of Agriculture Umudike, P. M. B. 7276, Umuahia, Abia State, Nigeria.

Abstract

This study was conducted for 4 months in the quest to discover natural materials, especially of plant origin, capable of substituting the roles of synthetic materials, especially drugs, in reproductive enhancement of livestock species. Such natural materials will help eliminate the menace of residual effects of synthetic materials on livestock products and probably attract more revenue from them. A total of 24 New Zealand White (NZW) weaned rabbit bucks were used and the study was carried out in a Complete Randomized Design (CRD), comprising three treatments replicated four times; $M T_{1}$ (control), $M T_{2}$ and $M T_{3}$, containing 0 , 200 and $400 \mathrm{mg} / \mathrm{kg}$ body weight of Panax ginseng extracts (PGEs), respectively. Assessment for attainment of puberty started from the age of 11 - 14 weeks on a weekly basis and at $72 \mathrm{~h}$ interval thereafter by examining their ejaculate and preputial fluid smeared on a glass slide under a microscope for sperm cells. Semen was collected twice a week for 3 weeks after maturity (6 months old) with the aid of an artificial vagina (AV), using rabbit does as teasers. Semen analysis was done within 20 minutes of collection, following standard procedures. Libido was determined weekly for 3 weeks by recording the time it took the matured rabbit bucks to sniff, groom, and mount the rabbit doe in the initial instance (reaction time); and by counting the number of times the matured buck attempts to mount the doe per minute (libido score). Data generated from this study was analyzed using analysis of variance (ANOVA). Age at puberty $\left(M T_{1}=116.00\right.$ days; $M T_{2}=112.50$ days; $M T_{3}=100.50$ days $)$ was significantly $(P<0.05)$ lower in $M T_{3}(400 \mathrm{mg} / \mathrm{kg} \mathrm{b.w})$, and weight at puberty $\left(M T_{1}=1483.33\right.$ $\left.\mathrm{g} ; \mathrm{MT}_{2}=1475.00 \mathrm{~g} ; \mathrm{MT}_{3}=1378.50 \mathrm{~g}\right)$ recorded a dose dependent significant $(P<0.05)$ decrease in the male rabbits. Semen volume $\left(M T_{1}=0.95 \mathrm{~mL} ; M T_{2}=1.25 \mathrm{~mL} ; M T_{3}=1.55\right.$ $m L)$, total sperm count $\left(M T_{1}=115.00 \times 10^{6} ; M T_{2}=125.50 \times 10^{6} ; M T_{3}=146.20 \times 10^{6}\right)$, progressive sperm motility $\left(M T_{1}=78.50 \% ; M T_{2}=83.00 \% ; M T_{3}=82.30 \%\right)$, live sperm proportion $\left(M T_{1}=80.63 \% ; M T_{2}=85.40 \% ; M T_{3}=89.75 \%\right)$ and libido score $\left(M T_{1}=7.00\right.$ mounts $/ \mathrm{min} ; M T_{2}=9.00$ mounts $/ \mathrm{min} ; M T_{3}=11.50$ mounts $\left./ \mathrm{min}\right)$ were significantly $(P<0.05)$ higher in adult rabbit bucks administered PGEs, while reaction time $\left(M T_{1}=9.45 \mathrm{~s} ; M T_{2}=\right.$ $\left.3.15 \mathrm{~s} ; \mathrm{MT}_{3}=2.60 \mathrm{~s}\right)$ significantly $(P<0.05)$ decreased in $P G E s$ treated rabbits. This study shows that PGEs can orally be administered up to $400 \mathrm{mg} / \mathrm{kg}$ body weight in NZW rabbit bucks to enhance their reproductive potential, through early attainment of puberty, improved semen quality and enhanced libido.

Keywords: Ginseng, libido, puberty, rabbits, semen.

\section{Introduction}

Due to the residual effects of synthetic drugs used in livestock production (Iwuji et al., 2019), researchers are delving into studies on non-synthetic materials, especially of plant origin, for use in livestock production. Several plants have been widely studied for possible benefits in different aspects of animal production like nutrition, reproduction and health. Incidentally, most plants possess pharmacological properties which have been reported to be the reason for their therapeutic potentials (D'Cruz et al., 2010). 


\section{Ginseng in rabbit buck reproduction}

Ginseng, which is a plant having different species has been well studied, especially the 'panax' specie, and has been reported to possess antioxidant properties, enhance immune function and synthesis of nitric oxide (de Jong et al., 2005; Kim et al., 2005). Traditionally, ginseng is being used as an aphrodisiac and it has been reported that Panax ginseng enhances nitric oxide synthesis in corpora cavernosa endothelium; and ginsenosides, a major component of ginseng, enhances acetylcholine-induced and transmural nerve stimulation-activated relaxation associated with increased tissue cyclic guanosine monophosphate (Sandroni, 2001). A study in rats (Oremosu et al., 2013) reported that Panax ginseng increased serum levels of luteinizing hormone (LH) and follicle stimulating hormone (FSH) which increased spermatogenesis in the rats. Rats that received 5\% ginseng experienced increase in blood testosterone level with reduced prostate weight (Fahim et al., 1982). However, while plant species are applied in livestock production for purposes other than reproduction, the reproductive effects of these plants on the animals is of paramount consideration, especially when breeding animals are involved and considering that many plants and plant products have been reported to impede spermatogenesis in various animal species (Saba et al., 2009). Although plants are generally adjudged to aid fertility (Olatunji-Bello et al., 2009), they may also relatively hinder fertility (D'Cruz et al., 2010).

Improving the rabbit production industry in Nigeria, which has been regarded as emergent or rudimentary (Iwuji et al., 2019), will include enhancing or optimizing their reproductive ability. Although rabbits are regarded as highly prolific animals (Iwuji, 2016), they are also prone to reproductive impediments or difficulties emanating from different causes, which may be environmental, nutritional, physiological, and managerial or pathogenic (Mailafia et al., 2010). It is possible that Panax ginseng may enhance reproductive abilities of rabbit bucks as reported in mice and rodents treated with Panax ginseng (Leung and Wong, 2013). Earlier studies on Panax ginseng with rabbits recorded significant increases in serum levels of follicle stimulating hormone (FSH), testosterone (T), triiodothyronine ( T 3 ) and tetraiodothyronine (T4) of treated rabbit bucks (Iwuji et al., 2017), while milk yield was significantly decreased in rabbit does administered Panax ginseng extracts (Iwuji et al., 2018). Sequel to the reported roles of Panax ginseng in different animal models, it became imperative for this experiment to evaluate the effects of Panax ginseng extracts (PGEs) on age and weight, at puberty, of growing rabbit bucks and their semen characteristics and libido, at maturity.

\section{Materials and methods \\ Location and site of the experiment}

The experiment lasted for 4 months and was carried out at the Department of Animal Science and Technology Teaching and Research Farm, Federal University of Technology, Owerri, Imo State. Imo State is situated in South Eastern agro-ecological zone of Nigeria, and lies between latitude $4^{\circ} 4^{\prime}$ and $6^{\circ} 3^{\prime} \mathrm{N}$, and longitude $6^{\circ} 15^{\prime}$ and $8^{\circ} 15^{\prime}$ E. Owerri is about $100 \mathrm{~m}$ above sea level with mean annual rainfall of $2500 \mathrm{~mm}$, temperature range of $26.5-27.5{ }^{\circ} \mathrm{C}$, and humidity range of $70-80 \%$. Dry season duration (months with less than $65 \mathrm{~mm}$ rainfall) is three months, which takes place during the months of December, January and February. (Ogbuewu et al., 2014).

\section{Experimental material}

The experimental material for this study is Panax ginseng extracts (PGEs). A commercially available capsulated pure 
Panax ginseng extracts (Mason natural ${ }^{\circledR}$ Korean Ginseng $518 \mathrm{mg}$ ) produced by MASON VITAMINS, INC. USA, was purchased from a reputable pharmacy. Each day, the contents of the Panax ginseng extracts capsule which weighed $500 \mathrm{mg}$ without the capsule were dissolved in distilled water at the rate of $200 \mathrm{mg} / \mathrm{mL}$ and administered orally to the rabbits used in this experiment, according to their treatment group. 20 capsules or $10,000 \mathrm{mg}$ of the Panax ginseng extracts (solute) were emptied into a graduated test tube. Distilled water (solvent) was then added and gradually stirred until all the solute were dissolved in the solvent and the volume of the solution made up to $50 \mathrm{~mL}$.

\section{Experimental animals and their management}

Twenty four New Zealand White (NZW) growing rabbit bucks (average age of 2 months) were used for this study. The rabbits were purchased from a reputable farm in Umuahia, Abia State. On arrival, the rabbits were housed separately in two hutches of twelve cages each and allowed two weeks to acclimatize before administering the treatments. During the acclimatization period, the rabbits were injected with $0.1 \mathrm{~mL}$ vitoxy (an antibiotic) as a prophylactic measure. The rabbits were then divided into three experimental groups and randomLy allocated to three treatments; $\mathrm{MT}_{1}, \mathrm{MT}_{2}$ and $\mathrm{MT}_{3}$; containing 0, 200 and $400 \mathrm{mg}$ PGEs per $\mathrm{kg}$ body weight, respectively. The treatments were orally given to the rabbits, using a syringe, between the hours of 7am and 9am, daily. Feed and water were given freely to the animals, while other standard management practices described by Mailafia et al. (2010) were carried out throughout the experiment.

\section{Age and weight at puberty}

The age and weight of the growing rabbit bucks at puberty were determined and recorded. The assessment for attainment of puberty started from the age of $11-14$ weeks on a weekly basis and at $72 \mathrm{~h}$ interval thereafter by examining their ejaculate and preputial fluid smeared on a glass slide under a microscope for sperm cells (Ewuola and Egbunike, 2010).

\section{Semen collection and evaluation}

Semen was collected from the rabbit bucks at an average age of 6 months with the aid of teaser does, using artificial vagina (AV) as described by Herbert and Adejumo (1995). The bucks were trained to ejaculate into the AV for 2 weeks, after which semen for analysis was collected twice within the $4^{\text {th }}$ week of the experiment at 3 days interval between the hours of 8.00 am and $9.00 \mathrm{am}$. Collected semen were analyzed immediately after liquefaction, following procedures outlined by Adeyemi et al. (2014). Semen volume was read off the graduated collection tube in the AV. Concentration of spermatozoa per $\mathrm{mL}$ was measured with an improved Neubauer haemocytometer. Motility was estimated from a small representative drop of semen that was held at temperature of $37{ }^{\circ} \mathrm{C}$. Smears were made from each ejaculate for evaluation of sperm morphology and for determining the proportion of abnormal spermatozoa. The differential staining (one drop of semen to two drops of eosin) on a slide and observation under the microscope aided the determination of the total live sperm. Total spermatozoa per ejaculate were calculated by multiplying semen volume by sperm concentration.

\section{Reaction time and libido}

Reaction time and libido of the rabbit bucks were assessed and recorded weekly through the introduction of a teaser doe to the bucks and monitoring their sex drive. Reaction time was measured as the time it took the rabbit buck to sniff, groom, and mount the rabbit doe, while libido score was measured as the number of times the buck attempts to mount the doe per minute. Both parameters were measured with the aid of an electronic 


\section{Ginseng in rabbit buck reproduction}

stop watch.

\section{Experimental design and data analysis}

The experiment was carried out in a Complete Randomized Design (CRD). It was made up of three treatments; $\mathrm{MT}_{1}, \mathrm{MT}_{2}$ and $\mathrm{MT}_{3}$ containing 0,200 , and $400 \mathrm{mg}$ of Panax ginseng extracts (PGEs), respectively. Each treatment contained 8 rabbits with 4 replicates of 2 rabbits per replicate. The statistical model for this experiment is;

$$
\begin{aligned}
& \mathrm{Y}_{\mathrm{ij}}=\mu+\mathrm{T}_{\mathrm{i}}+\mathrm{e}_{\mathrm{ij}} \\
& \text { Where; } \\
& \mathrm{Y}_{\mathrm{ij}}=\text { Individual observation } \\
& \mu=\text { Overall mean } \\
& \mathrm{T}_{\mathrm{i}}=\text { Treatment effect } \\
& \mathrm{e}_{\mathrm{ij}}=\text { Random error, which is } \\
& \text { assumed to be independently, } \\
& \text { identically and normally } \\
& \text { distributed with zero mean and } \\
& \text { constant variance. }
\end{aligned}
$$

Data collected were subjected to analysis of variance (ANOVA) using SAS (2004). Significantly $(\mathrm{P}<0.05)$ different means were separated using the same software.

\section{Results and discussion}

\section{Age and weight at puberty}

Table 1 presents the average ages and weights of the growing rabbit bucks at puberty. Weight of rabbit bucks on $\mathrm{MT}_{3}$ $(1378.50 \mathrm{~g})$ were significantly $(\mathrm{P}<0.05)$ lower than those of bucks on $\mathrm{MT}_{1}(1483.33$ g) and $\mathrm{MT}_{2}(1475.00 \mathrm{~g})$, while bucks on $\mathrm{MT}_{1}$ significantly $(\mathrm{P}<0.05)$ recorded the highest weight at puberty.
Age and weight are among the factors affecting attainment of puberty in farm animals and since puberty is a gradual quantitative phenomenon rather than an acute and qualitative endocrinological event, growth rate then becomes a factor intertwined with age and live weight of the animal when puberty is considered (Lawrence and Fowler, 2002). The significant $(\mathrm{P}<0.05)$ decrease in age and weight at which the male growing rabbits administered PGEs attained puberty is an indication that PGEs can be used to hasten onset of puberty in male rabbits, thereby enhancing reproductive efficiency and c o r r o b o r a t i n g t h e spermatogenic/androgenic (endocrine effects) and fertility enhancing properties of ginseng reported in many literatures (Salvati et al., 1996; Schardt, 1999; Chen et al., 1999). The reduced age and weight at puberty of the male rabbits treated with PGEs is probably due to increased growth rate recorded in these animals. This is sequel to the fact that the relationship between growth rate, age and live weight at puberty are very complex and it is virtually impossible to separate the effects of growth rate per se from those of live weight and/or age. Hence selection for high growth rates in animals under domestication has led to puberty being attained at younger ages and sometimes at lighter live weights and therefore at lower proportions of mature live weight, compared with the situation in unselected populations from which such animals have been derived (Lawrence and Fowler, 2002).

Table 1: Average age and weight at puberty of growing rabbit bucks administered Panax ginseng extracts

\begin{tabular}{lllll}
\hline Parameters & MT $_{1}$ & MT $_{2}$ & MT $_{3}$ & SEM \\
\hline Age (days) & $116.00^{\mathrm{a}}$ & $112.50^{\mathrm{a}}$ & $100.50^{\mathrm{b}}$ & 2.23 \\
Weight (g) & $1483.33^{\mathrm{a}}$ & $1475.00^{\mathrm{b}}$ & $1378.50^{\mathrm{c}}$ & 18.19 \\
\hline
\end{tabular}

${ }^{a b c}$ : Means within a row with different superscripts are significantly $(\mathrm{P}<0.05)$ different. $\mathrm{MT}=$ Male treatment; SEM = Standard error of means. 


\section{Iwuji, Herbert, Oguike and Obikaonu}

\section{Semen characteristics and libido}

Table 2 presents the semen characteristics and libido evaluation results of the experimental rabbits. Semen volume was significantly $(\mathrm{P}<0.05)$ higher in rabbits on $\mathrm{MT}_{3}(1.55 \mathrm{~mL})$ than in rabbits on $\mathrm{MT}_{1}(0.95$ $\mathrm{mL})$, but similar $(\mathrm{P}>0.05)$ to the semen volume of the rabbits in $\mathrm{MT}_{2}(1.25 \mathrm{~mL})$ which was similar $(\mathrm{P}>0.05)$ to $\mathrm{MT}_{1}$. Total sperm count was significantly $(\mathrm{P}<0.05)$ higher in rabbits on $\mathrm{MT}_{3}\left(146.20 \times 10^{6}\right)$ than in rabbits on $\mathrm{MT}_{2}\left(125.50 \times 10^{6}\right)$ which was significantly $(\mathrm{P}<0.05)$ higher than total sperm count of rabbits on $\mathrm{MT}_{1}(115.00 \mathrm{x}$ $\left.10^{6}\right)$. Sperm concentration of the experimental rabbits was significantly $(\mathrm{P}<0.05)$ higher in rabbits on $\mathrm{MT}_{1}(123.68 \mathrm{x}$ $\left.10^{6} / \mathrm{mL}\right)$ than in rabbits on $\mathrm{MT}_{2}(98.40 \mathrm{x}$ $\left.10^{6} / \mathrm{mL}\right)$ and $\mathrm{MT}_{3}\left(96.16 \times 10^{6} / \mathrm{mL}\right)$ which were similar $(\mathrm{P}>0.05)$. Rabbit bucks on $\mathrm{MT}_{2}$ $(83.00 \%)$ and $\mathrm{MT}_{3}(82.30 \%)$ have similar $(\mathrm{P}>0.05)$ percentage of progressive motile spermatozoa, which were significantly $(\mathrm{P}<0.05)$ higher than percentage of progressive motile spermatozoa recorded for rabbits on $\mathrm{MT}_{1}(78.50 \%)$. Percent live sperm proportion was significantly $(\mathrm{P}<0.05)$ higher in rabbits on $\mathrm{MT}_{3}(89.75 \%)$ than in rabbits on $\mathrm{MT}_{2}(85.40 \%)$ which was significantly $(\mathrm{P}<0.05)$ higher than the percent live sperm proportion observed in rabbits on $\mathrm{MT}_{1}(80.63 \%)$. The percent abnormal sperm of the rabbits was similar between rabbits on $\mathrm{MT}_{1}(14.01 \%)$ and $\mathrm{MT}_{2}$ $(12.60 \%)$, but significantly $(\mathrm{P}<0.05)$ lower in rabbits on $\mathrm{MT}_{3}(9.45 \%)$. Reaction time was significantly $(\mathrm{P}<0.05)$ higher in rabbits on $\mathrm{MT}_{1}(9.45$ secs $)$ than in rabbits on $\mathrm{MT}_{2}$ (3.15 secs) and $\mathrm{MT}_{3}(2.60 \mathrm{secs})$ which were similar $(\mathrm{P}>0.05)$. Libido score was significantly $(\mathrm{P}<0.05)$ higher in rabbits on $\mathrm{MT}_{3}$ (11.50 mounts/min.) than in rabbits on $\mathrm{MT}_{2}$ (9.00 mounts/min.) which was significantly $(\mathrm{P}<0.05)$ higher than libido score for rabbits on $\mathrm{MT}_{1} \quad(7.00$ mounts/min.).

Semen analysis of the adult rabbit bucks recorded a dose dependent increase in the volume, which became significant at 400 mg administration of Panax ginseng extracts. Previous studies have recorded increased and decreased semen volumes in different animals treated with Panax ginseng (Akram et al., 2010; Abdel-Hamed et al., 2014). However, since Panax ginseng has been reported to enhance endocrine and tissue functions of organs and increase blood flow through smooth muscle relaxation (Park et al., 2005), the significant increase in the semen volume of $\mathrm{MT}_{3}$ rabbits can be appropriately concluded to be the effect of PGEs on the accessory sex glands that produce fluids which forms greater portion of the semen volume (Frandson et al., 2009). Furthermore, variation in animal species and ginsenoside content, coupled with difference in age and method of extract preparation of the ginseng used, could also be contributory factors in the conflicting semen volume obtained in experiments with ginseng (Akram et al., 2010; Abdel-Hamed et al., 2014). Total sperm count of the experimental rabbits recorded a dose dependent increase, which is similar to total sperm count results in most studies with Panax ginseng, recorded in both animal and human models (Hosseini et al., 2010; Leung and Wong, 2013). The significantly lower sperm concentrations recorded in animals receiving PGEs $\left(\mathrm{MT}_{2}\right.$ and $\left.\mathrm{MT}_{3}\right)$ were due to the increased volume recorded in these groups; this will not affect fertility of the animals since total sperm count was significantly higher in the PGEs treated animals. The significantly higher percentages of progressive motile spermatozoa, live sperm proportion and low abnormal sperm percent recorded in the rabbit bucks receiving PGEs could be due to L-arginine content (Polan et al., 2004), antioxidant property, nitric oxide 


\section{Ginseng in rabbit buck reproduction}

release and hormonal effects of Panax ginseng (Kim et al., 2005; Jang et al., 2012; Al-Ebady et al., 2012). Other properties of Panax ginseng like anti-aging, protein synthesis and steroid-like effects, among others, may have also played a role in the semen characteristics of these rabbits receiving PGEs (Metori et al., 1997).

Reaction time in seconds, which is the time it takes the rabbit buck to sniff, groom and try to mount the doe for intromission was significantly lower in the rabbits receiving PGEs. This means that it took lesser time, from the time of introduction of the rabbit does into the cages of the PGEs treated rabbit bucks, for the rabbits to mount the rabbit does. Libido score (mounts/minute) was significantly higher in a dose dependent manner among the experimental rabbits, showing that PGEs has a strong positive effect on libido of the rabbit bucks, which is in agreement with earlier studies (Yoshimura et al., 1998; Sandroni, 2001; Jang et al., 2008). These effects were attributed to the ability of PGEs to cause enhanced erection in the animals through the release of nitric oxide (NO) which relaxes the smooth muscles of the erectile tissues of the penis (corpus cavernosum) for increased blood flow. The ginsenoside, Rg1 (a component of ginseng) has been implicated for this role (Wang et al., 2010). Furthermore, studies on rodents reveals that Panax ginseng or ginsenoside Rg1 can facilitate copulatory behaviour and a dose dependent increase in mounting, intromission, and penis licking in mice which are exposed to estrous females; but such effects were not observed in mice treated with ginsenoside Rb1, Rb2, and Ro (Yoshimura et al., 1998).

Table 2: Semen characteristics and libido of adult rabbit bucks administeredPanax ginseng extracts

\begin{tabular}{lllll}
\hline Parameters & $\mathbf{M T}_{\mathbf{1}}$ & $\mathbf{M T}_{\mathbf{2}}$ & $\mathbf{M T}_{\mathbf{3}}$ & $\mathbf{S E M}$ \\
\hline Semen volume $(\mathrm{mL})$ & $0.95^{\mathrm{b}}$ & $1.25^{\mathrm{ab}}$ & $1.55^{\mathrm{a}}$ & 0.18 \\
Total sperm $\left(\mathrm{x} \mathrm{10^{6 }}\right)$ & $115.00^{\mathrm{c}}$ & $125.50^{\mathrm{b}}$ & $146.20^{\mathrm{a}}$ & 6.63 \\
Sperm concentration $(\mathrm{x} \mathrm{10} / \mathrm{mL})$ & $123.68^{\mathrm{a}}$ & $98.40^{\mathrm{b}}$ & $96.16^{\mathrm{b}}$ & 4.75 \\
Progressive sperm motility $(\%)$ & $78.50^{\mathrm{b}}$ & $83.00^{\mathrm{a}}$ & $82.30^{\mathrm{a}}$ & 1.22 \\
Live sperm proportion (\%) & $80.63^{\mathrm{c}}$ & $85.40^{\mathrm{b}}$ & $89.75^{\mathrm{a}}$ & 1.38 \\
Abnormal sperm (\%) & $14.01^{\mathrm{a}}$ & $12.60^{\mathrm{a}}$ & $9.45^{\mathrm{b}}$ & 1.02 \\
Reaction time (secs) & $9.45^{\mathrm{a}}$ & $3.15^{\mathrm{b}}$ & $2.60^{\mathrm{b}}$ & 1.18 \\
Libido score (mounts/minute) & $7.00^{\mathrm{c}}$ & $9.00^{\mathrm{b}}$ & $11.50^{\mathrm{a}}$ & 0.62 \\
\hline abc: Means within a row with different superscripts are significantly $(\mathrm{P}<0.05)$ different. MT $=$ Male treatment; SEM \\
= Standard error of means.
\end{tabular}

The male sex steroid, testosterone, is synthesized in the Leydig cells under the control of luteinizing hormone (LH), which is produced by the anterior pituitary (Leung and Wong, 2013). Testosterone levels are strongly correlated with libido and studies with Panax ginseng in rats have been reported to significantly increase blood testosterone levels. Ginsenoside Rb1 found in ginseng has been reported to increase the secretion of luteinizing hormone (LH) by acting directly on the anterior pituitary gland (Tsai et al., 2003). It has also been suggested that ginseng may regulate the pituitary-testis axis at both hormonal and neuronal levels (Shi et al., 2013).

\section{Conclusion}

The relevance of Panax ginseng extracts (PGEs) in rabbit buck production is being demonstrated in this study, especially in respect of their reproduction. Rabbit farmers can use up to $400 \mathrm{mg} / \mathrm{mL}$ of PGEs to induce early puberty with enhanced semen quality and libido. This will serve as a veritable option to synthetic drugs used for same purpose.

\section{Acknowledgement}

This study was funded by Tertiary 
Education Trust Fund, through Federal University of Technology Owerri (Ref: FUT/DVC (Acad.)/GEN 92/51).

\section{References}

Abdel-Hamed, O. A., EL-Sayed, A. I., Iraqi, M. M., Saad, A. M. and R a d wan, A. A. 2014 . Comparative evaluation of different herbal formula and LCarnitine on reproductive performance of male Moshtohor rabbits. $2^{\text {nd }}$ Int. Conf. on Biotechnology Applications in Agriculture (ICBAA), Benha University Moshtohor and Hurghada, Egypt. Pp. $11-17$.

Adeyemi, A. A., Ewuola, E. O. and Tewe, O. O. 2014. Testosterone, libido assessment and semen characteristics of rabbits fed supplemental Moringa oleifera leaf meal. Nigerian Journal of Animal Science, 16(1): 13-19.

Akram, H., Samad, Z., Firouz, G. P. and Abbas, A. 2010. Effects of vitamin $\mathrm{E}$ and ginseng extract on fertility changes induced by cyclophosphamide in rats. Journal of Reproduction and Infertility, 11 (4): $227-237$.

AL-Ebady, A. S., Hussain, S. O., ALBadry, K. I. and Ibrahim, F. F. 2012. Effect of adding Larginine on some parameters of bull sperms after freezing in liquid nitrogen $\left(-196^{\circ} \mathrm{C}\right) . A L-$ Qadisiya Journal of Veterinary Medicine and Sciences, 11 (2): $156-161$

Chen, J. C., Xu, M. X., Chen, L. D., Chen, Y. N., and Chiu, T. H. 1999. Effect of panax notoginseng extracts on inferior sperm motility in vitro. American Journal of Chinese Medicine, 27 (1): 123 - 128.
D'Cruz, S. C., Vaithinathan, S., Jubendradass, R. and Mathur, P. P. 2010. Effects of plants and plant products on the testis. Asian J Androl. Jul 2010; 12(4): 468-479.

De Jong, J. R., Vlaeyen, J. W. S., Onghena, P., Cuypers, C., den Hollander, M. and Ruijgrok, J. 2005. Reduction of pain-related fear in complex regional pain syndrome type 1: The application of graded exposure in vivo. Pain, 116: $264-275$.

Ewuola, E. O. and Egbunike, G. N. 2010. Effects of dietary fumonisin $\mathrm{B}_{1}$ on the onset of puberty, semen quality, fertility rates and testicular morphology in male rabbits. Reproduction; 139: 439 445.

Fahim, M. S., Fahim, Z., Harman, J. M., Clevenger, T. E., Mullins, W. and Hafez, S. E. 1982. Effect of Panax ginseng on testosterone level and prostate in male rats. Systems Biology in Reproductive Medicine, 8(4): 261 - 263.

Frandson, R. D., Wilke, W. L. and Fails, A. D. 2009. Anatomy and Physiology of Farm animals $\left(7^{\text {th }}\right.$ edn). Wil ey-Blackwell Publishing, USA.

Herbert, U. and Adejumo, D.O. 1995. Construction and evaluation of an artificial Vagina for collecting rabbit semen. Delta Agric. (2): 99 -108 .

Hosseini, A., Zare, S., Ghaderi Pakdel, F. and Ahmadi, A. 2010. Effects of Vitamin E and Ginseng Extract on Fertility Changes Induced by Cyclophosphamide in Rats. Journal of Reproduction and Infertility, 11 (4): 227 - 237.

Iwuji, T. C. 2016. Growth performance and Physiological responses of 


\section{Ginseng in rabbit buck reproduction}

Rabbits Administered Panax ginseng Extracts. Ph.D Thesis submitted to the department of Animal Breeding and Physiology, Michael Okpara University of Agriculture, Umudike, Umuahia, Abia State, Nigeria.

Iwuji, T. C., Herbert, U and Oguike, $M$. A. 2018. Effect of Panax Ginseng Extracts on Milk Yield of New Zealand White Rabbits. 43rd Annual Conference of the Nigerian Society for Animal Production (NSAP), March 18th - 22nd 2018, FUT Owerri, Pp. 152-154.

Iwuji, T. C., Herbert, U., Ogbuewu, I. P. and Etuk, I. F. 2017. Serum levels of selected hormones in adult New Zealand White rabbit bucks administered Panax ginseng extracts. Proceedings of $6^{\text {th }}$ ASAN-NIAS Joint Annual Conference, Abuja, $10^{\text {th }}-14^{\text {th }}$ September, 2017. Pp 130-133.

Iwuji, T. C., Uzor, V. C., Kadurumba, $O$. E., Okere, P. C. and Egenuka, F. C. 2019. Reproductive characteristics of adult rabbit bucks fed diets containing Dialium guineense leaf meal. $8^{\text {th }}$ Animal Science Association of Nigeria (ASAN) and Nigeria Institute of Animal Science (NIAS) joint conference, Abia State, Nigeria. 8 - 12 September, Pp. 371-374.

Jang, D. J, Lee, M. S, Shin, B. C, Lee, Y. C. 2008. Ernst E. Red ginseng for treating erectile dysfunction: a systematic review. British Journal of Clinical Pharmacology, 66: 444 - 450.

Jang, M., Min, J., In, J. and Yang, D. 2012. Effects of red ginseng extract on the epididymal sperm motility of mice exposed to ethanol. International Journal of Toxicology, 30 (4): 435 - 442.

Kim, S. H., Park, K. S., Chang, M. J. and Sung, J. H. 2005. Effects of Panax ginseng extract on exercise-induced oxidative stress. Journal of Sports Medicine and. Physical Fitness, 45 (2): $178-182$.

Lawrence, T. L. J. and Fowler, V. 2002. Growth of farm animals, $2^{\text {nd }}$ edn. CABI Publishing, Wallingford Oxfordshire, UK, 430 pp.

Leung, K. W. and Wong, A. S. 2013. Ginseng and male reproductive function. Spermatogenesis Volume 3 , Issue 3.

Mailafia, S., Onakpa, M. M. and Owoleke, O. E. 2010. Problems and prospects of rabbit production in Nigeria - A review. Bayero Journal of Pure and Applied Science, 3 (2): 20-25.

Metori, K., Furutsu, M. and Takahashi, S. 1997. The preventive effect of ginseng with du-zhong leaf on protein metabolism in aging. Biological and Pharmaceutical. Bulletin, 20 (3): 237-242.

Ogbuewu, I. P., Okoli, I. C. and Iloeje, M. U. 2009. Semen quality characteristics, reaction time, testis weight and seminiferous tubule diameter of buck rabbits fed neem (Azadirachta indica $A$. Juss) leaf meal based diets. Iranian Journal of Reproductive Medicine, 7:23-28.

Olatunji-Bello, I. I., Ijiwole2 T. and Awobajo F. O. 2009. Evaluation of the deleterious effects of aqueous fruit extract of Abelmoschus esculentus (Okro fruit) ond some male reproductive parameters in sprague dawley rats. J Phytol. 
$1: 461-468$.

Oremosu, A.A., Arowosaye, V. O., Akang, E. N. and Bassey, R. B. 2013. Effects of Cissus populnea and Panax ginseng on flutamideinduced testicular defect in prepubertal male rats. British Journal of Medicine and Medical Research, 3 (1): $173-181$.

Park, J. D., Rhee, D. K. and Lee, Y. H. 2005. Biological activities and chemistry of saponins from Panax ginseng C. A. Meyer. Phytochemistry Reviews, 4: 159 175.

Polan, M. L., Hochberd, R. B., Trant, A. S. and Wuh, H. C. 2004. Estrogen bioassay of ginseng extract and ArginMax, a nutritional supplement for the enhancement of female sexual function. Journal of Womens Health (Larchmt), 13 (4): 427 430.

Saba, A. B., Oridupa, O. A., Oyeyemi, M. O. and Osanyigbe, O. D. 2009. Spermatozoa morphology and characteristics of male wistar rats administered with ethanolic extract of Lagenaria breviflora roberts. Afr J Biotechnol. 8: 1170 -1175 .

Salvati, G., Genovesi, G., Marcellini, L., Paolini, P., De Nuccio, I., Pepe, M. and Re, M. 1996. Effects of Panax Ginseng C.A. Meyer saponins on male fertility. Panminerva Medica, 38 (4): 249 54.

Sandroni, P. 2001. Aphrodisiacs past and present: a historical review. Clinical Autonomic Research, 11 (5): $303-307$.
SAS (Staistical Analysis System) Institute Inc. 2004. SAS/STAT ${ }^{\circledR}$ 9.1 User's Guide. Cary, NC: SAS Institute Inc.

Schardt, D. 1999. Ginseng. Nutrition Action Health Letter, 26 (4): 10 12.

Shi, J., Xue, W., Zhao, W. J. and Li, K. X. 2013. Pharmacokinetics and dopamine/acetylcholine releasing effects of ginsenoside $\mathrm{Re}$ in hippocampus and $\mathrm{mPFC}$ of freely m o ving ra t s. A c t a Pharmacologica Sinica, 34: 214 20.

Tsai, S. C., Chiao, Y. C., Lu, C. C. and Wang, P. S. 2003. Stimulation of the secretion of luteinizing hormone by ginsenoside-Rb1 in male rats. Chinese Journal of Physiology, 46: 1-7.

Wang, X., Chu, S., Qian, T., Chen, J. and Zhang, J. 2010. Ginsenoside Rg1 improves male copulatory behavior via nitric oxide/cyclic guanosine monophosphate pathway. Journal of Sexual Medicine, 7: $743-50$.

Yoshimura, H., Kimura, N. and Sugiura, K. 1998. Preventive effects of various ginseng saponins on the development of copulatory disorder induced by prolonged individual housing in male mice. Methods and Findings in Experimental Clinical Pharmacology, 20:59-64.

Received: $19^{\text {th }}$ September, 2019 Accepted: $17^{\text {th }}$ February, 2020 